\title{
Hormone Activity Induction
}

National Cancer Institute

\section{Source}

National Cancer Institute. Hormone Activity Induction. NCI Thesaurus. Code C41519.

Hormone Activity Induction involves initiation of the biological function of a biochemical substance (typically secreted by an endocrine gland) having a selective regulatory effect on the activity of a specific cell type(s) or organ(s). 